\title{
Kemampuan Berpikir Kritis Mahasiswa pada Materi Optik Saat Proses Pembelajaran dengan CCM-CCA Berbantuan Eksperimen Virtual
}

\author{
${ }^{1}$ Muh. Makhrus, ${ }^{2}$ Syahrial Ayub, ${ }^{3}$ Wahyudi, ${ }^{4}$ Ni Nyoman Putu Sri Verawati, \\ ${ }^{5}$ Ahmad Busyairi \\ 1,2,3,4,5 Program Studi Pendidikan Fisika, Fakultas Keguruan dan Ilmu Pendidikan, Universitas \\ Mataram, J1. Majapahit 62 Mataram, Indonesia 83125
}

Email Korespondensi: makhrus.fkip@unram.ac.id

\begin{tabular}{|c|c|}
\hline Article Info & Abstract \\
\hline $\begin{array}{l}\text { Article History } \\
\text { Received: October } 2020 \\
\text { Revised: December } 2020 \\
\text { Published: December } 2020\end{array}$ & \multirow{2}{*}{$\begin{array}{l}\text { This study aims to train students' critical thinking skills during the learning } \\
\text { process using CCM-CCA assisted by virtual experiments. The material used for } \\
\text { research in optics. This type of research uses a quantitative approach. The } \\
\text { subjects in the research were } 30 \text { physics education students at a university in } \\
\text { NTB. The ability to think critically during the learning process is trained with } \\
\text { student worksheets equipped with instruments for critical thinking. Learning is } \\
\text { carried out for } 3 \text { meetings. The results showed that there was an increase in } \\
\text { students 'critical thinking skills from the low category with an average score of } \\
38 \text { to the high category with an average score of } 75 \text {. This fact shows that CCM- } \\
\text { CCA learning assisted with virtual experiments can train and even improve } \\
\text { students' critical thinking skills in Optical material. }\end{array}$} \\
\hline $\begin{array}{l}\text { Keywords } \\
\text { Critical Thinking Ski } \\
\text { CCM-CCA; Virtual } \\
\text { Experiment; Optics }\end{array}$ & \\
\hline Info & A t l l \\
\hline $\begin{array}{l}\text { Seja } \\
\text { Diter } \\
\text { Dire } \\
\text { Dipu }\end{array}$ & \multirow{2}{*}{$\begin{array}{l}\text { Penelitian ini bertujuan untuk melatih kemampuan berpikir kritis mahasiswa } \\
\text { pada saat proses pembelajaran dengan CCM-CCA berbantuan virtual } \\
\text { experiment. Materi yang dijadikan penelitian adalah Optik. Jenis penelitian ini } \\
\text { menggunakan pendekatan kuantitatif. Subjek dalam penelitian yaitu } 30 \\
\text { mahasiswa Program Studi Pendidikan Fisika di salah satu universitas di NTB. } \\
\text { Kemampuan berpikir kritis pada saat proses pembelajaran dilatih dengan } \\
\text { lembar kerja mahasiswa (LKM) yang dilengkapi instrumen penilaian } \\
\text { kemampuan berpikir kritis. Pembelajaran dilaksanakan selama } 3 \text { kali } \\
\text { pertemuan. Hasil penelitian menunjukkan adanya peningkatan kemampuan } \\
\text { berpikir kritis mahasiswa dari kategori rendah dengan skor rata-rata } 38 \text { menjadi } \\
\text { kategori tinggi dengan skor rata-rata } 75 \text {. Fakta ini menunjukkan pembelajaran } \\
\text { dengan menggunakan CCM-CCA berbantuan virtual experiment mampu } \\
\text { meningkatkan kemampuan berpikir kritis mahasiswa pada materi Optik. }\end{array}$} \\
\hline $\begin{array}{l}\text { Kata kunci } \\
\text { Keterampilan Berpikir } \\
\text { Kritis; CCM-CCA; Virtual } \\
\text { Experiment; Optik }\end{array}$ & \\
\hline \multicolumn{2}{|r|}{$\begin{array}{l}\text { Ayub, S., Wahyudi, W., Verawati, NNSP., Busyairi, A. (2020). Kemampuan } \\
\text { ada Materi Optik Saat Proses Pembelajaran dengan Ccm-Cca Berbantuan } \\
\text { urnal, } 4(2), 143-148 \text {. }\end{array}$} \\
\hline
\end{tabular}

\section{PENDAHULUAN}

Pembelajaran abad 21 menitikberatkan hasil belajar pada keterampilan berpikir. Ada empat keterampilan yang diharapkan ada pada pendidik maupun peserta didik yaitu berpikir kritis dan pemecahan masalah, inovasi dan kreativitas, kolaborasi, dan komunikasi. Berpikir kritis penting dimiliki oleh peserta didik di tingkat sekolah dasar hingga perguruan tinggi. Berpikir kritis merupakan keterampilan yang menjadi prioritas dalam pembelajaran dan penelitian berbagai disiplin ilmu sesuai tuntutan pembelajaran abad 21 (Fitriani, Asy'ari, Zubaidah, \& Mahanal, 2019). Mahasiswa selaku pebelajar dituntut memiliki keterampilan berpikir kritis karena keterampilan ini penting dalam menyelesaikan persoalan dan 
pengambilan keputusan saat dikehidupan nyata. Permasalahan di era global ini begitu kompleks sehingga perlunya kemampuan berpikir kritis dalam menyelesaikannya. Informasi di era global ini juga begitu cepat tersebar sehingga diperlukan analisis mendalam terkait kebenaran informasi tersebut (Santi, Soendjoto, \& Winarti, 2018). Keterampilan berpikir kritis akan membuat seseorang dalam mengambil keputusan atau tindakan yang tepat terhadap permasalahannya (Firdaus \& Wilujeng, 2018). Kemampuan berpikir kritis merupakan modal penting yang harus dimiliki seseorang dalam menghadapi perkembangan ilmu pengetahuan dan teknologi (Dwijananti \& Yulianti, 2010). Sejalan dengan itu, seseorang yang memiliki kemampuan berpikir kritis yang kurang akan mengalami kesulitan saat bersaing di era perkembangan teknologi dan informasi ini (Pradana, Parno, \& Handayanto, 2017). Mengingat begitu pentingnya kemampuan berpikir kritis ini, maka perlunya melatih kemampuan berpikir kritis untuk membekali peserta didik bahkan mahasiswa dalam menghadapai kehidupan. Kemampuan berpikir kritis setiap orang berbeda-beda, tergantung seberapa sering kemampuan tersebut dilatih (Santi et al., 2018).

Satu diantara berbagai model pembelajaran yang mampu melatih kemampuan berpikir kritis adalah model pembelajaran CCM-CCA. CCM-CCA merupakan singkatan dari Conceptual Change Model with Cognitive Conflict Approach. Model pembelajaran ini mampu memfasilitiasi perubahan konsep pada ranah kognitif seseorang dengan melatih kemampuan berpikirnya untuk menganalisis suatu permasalahan. CCM-CCA adalah model pembelajaran yang membantu peserta didik membangun pengetahuannya sendiri dengan cara melibatkan peserta didik dalam pembelajaran aktif untuk mencari konsep yang benar melalui percobaan atau demonstrasi (Makhrus, 2018). Konflik kognitif pada CCM-CCA ini membantu peserta didik dalam mengkonfrontasi pengetahuannya yang salah. Konflik kognitif merupakan ketidaksesuaian antara konsepsi yang dimiliki peserta didik dengan konsep baru yang diajarkan (Hidayatullah, Makhrus, \& Gunada, 2018). Konflik kognitif dapat dimunculkan dengan melakukan pembelajaran berbasis eksperimen atau demonstrasi yang berbeda dengan konsep awal peserta didik. Fungsi eksperimen dalam pembelajaran bukan hanya sekedar mengambil data percobaan melainkan lebih ke arah pembuktian konsepsi peserta didik itu sendiri. Penggunaan virtual experiment pada pembelajaran CCM-CCA ini dimaksudkan untuk membantu pemunculan konflik kognitif sehingga melatih kemampuan bepikir peserta didik. Model perubahan konseptual dengan pendekatan konflik kognitif (Conceptual Change Model with Cognitive Conflict Approach) yang disingkat menjadi CCM CCA adalah model pembelajaran yang dikembangkan dengan tujuan untuk memfasilitasi perubahan konsep pada mahasiswa dengan cara mereduksi miskonsepsinya (Makhrus, Widodo, \& Agustini, 2018). Pembelajaran dengan pendekatan konflik kognitif ini berpijak pada konstruktivisme Piagetian dan Vygotskian. Model pembelajaran CCM CCA merupakan teori atau model pembelajaran baru untuk memfasilitasi terjadinya perubahan konseptual pada Mahasiswa. Penggunaan model pembelajaran CCM CCA akan semakin maksimal jika dikolaborasikan dengan penggunaan media pembelajaran baik berupa media sederhana maupun berbasis teknologi. Salah satu media yang dapat membantu pembelajaran yaitu media virtual experiment. Media ini membantu memvisualisasikan konsep yang abstrak terkait materi optik. Virtual experiment memberikan suatu visual atau penjelasan tentang situasi melalui simulasi komputer. Peserta didik berpeluang berinteraksi untuk menanggapi keadaan tersebut (Simbolon \& Sahyar, 2018). Media virtual experiment adalah eksperimen 
dengan memanfaatkan media virtual seperti simulasi komputer atau media laboratorium virtual. Keunggulan laboraturium virtual yakni bisa menjelaskan konsep abstrak yang tidak bisa dijelaskan melalui penyampaian secara verbal (Saputra, Nur, \& Purnomo, 2015) dan virtual experiment menjadi solusi alternatif untuk alat laboratorium yang rusak (Fiscarelli, Bizelli, \& Fiscarelli, 2013).

Berdasarkan uraian di atas, penelitian ini bertujuan untuk melatih kemampuan berpikir kritis mahasiswa saat proses pembelajaran melalui pembelajaran CCM-CCA berbantuan virtual experiment pada materi optik. Adapun indikator berpikir kritis yang ingin dilatih saat proses pembelajaran yaitu klarifikasi dasar, keputusan dasar, inferensi, penjelasan lanjut, dan menalar.

\section{METODE}

Penelitian ini dilakukan di salah satu universitas wilayah NTB. Jenis penelitian ini menggunakan pendekatan kuantitatif. Adapun subjek dalam penelitian ini sejumlah 30 mahasiswa yang menempuh matakuliah fisika dasar materi optik. Instrumen yang digunakan untuk mengetahui kemampuan berpikir kritis mahasiswa saat proses pembelajaran adalah lembar kerja mahasiswa (LKM) yang dilengkapi dengan soal-soal berpikir kritis. Kemampuan berpikir kritis mahasiswa digolongkan ke dalam beberapa kategori seperti tabel berikut.

Tabel 1. Kriteria Berpikir Kritis

\begin{tabular}{cc}
\hline Skor Berpikir Kritis & Kategori \\
\hline $80 \leq$ Skor $<100$ & Sangat Tinggi \\
$60 \leq$ Skor $<80$ & Tinggi \\
$40 \leq$ Skor $<60$ & Sedang \\
$20 \leq$ Skor $<40$ & Rendah \\
$0 \leq$ Skor $<20$ & Sangat Rendah \\
\hline
\end{tabular}

\section{HASIL DAN PEMBAHASAN}

Pembelajaran dilaksanakan dengan menerapkan model CCM-CCA berbantuan virtual experiment pada materi optik. Jumlah mahasiswa yang ikut serta dalam pembelajaran sebanyak 30 mahasiswa yang mengambil matakuliah fisika dasar. Virtual experiment merupakan media yang kembangkan untuk membantu kegiatan percobaan/demonstrasi secara virtual (tanpa harus ke laboratorium). Media virtual experiment ini cocok membantu pembelajaran CCM-CCA dalam melaksanakan kegiatan yang tidak memungkinkan dilaksanakan di dalam laboratorium akibat terkendala alat dan bahan. Konsep ataupun percobaan yang abstrak dapat diamati melalui media virtual experiment sehingga mampu memunculkan konflik kogntif dan menciptakan perubahan konseptual pada mahasiswa. Sebelum dilakukan pembelajaran, mahasiswa diberikan tes awal untuk mengetahui kemampuan berpikir kritis mereka. Selanjutnya diberikan pembelajaran CCM-CCA berbantuan virtual experiment dan diukur kemampuan berpikir kritisnya saat pembelajaran menggunakan lembar kerja mahasiswa (LKM) yang dilengkapi instrumen tes berpikir kritis. Pembelajaran dilaksanakan dalam 3 pertemuan dengan 3 LKM berbeda yaitu LKM tentang pemantulan cahaya, LKM pembiasan cahaya, dan LKM tentang sinar istimewa pada lensa 
cekung dan cembung. Adapun rata-rata hasil kemampuan berpikir kritis mahasiswa pada materi optik tersebut dapat dilihat pada Tabel 2 berikut ini.

Tabel 2. Kemampuan Berpikir Kritis saat Pembelajaran dengan CCM-CCA berbantuan Virtual Experiment

\begin{tabular}{|c|c|c|c|}
\hline \multirow[b]{2}{*}{$\begin{array}{c}\text { Jumlah } \\
\text { Mahasiswa }\end{array}$} & \multirow[b]{2}{*}{$\begin{array}{c}\text { Indikator Kemampuan } \\
\text { Berpikir Kritis }\end{array}$} & \multicolumn{2}{|c|}{ Rata-rata Nilai } \\
\hline & & Pretest & $\begin{array}{c}\text { Saat Proses } \\
\text { Pembelajaran }\end{array}$ \\
\hline \multirow{6}{*}{30 Mahasiswa } & Klarifikasi dasar & 50 & 80 \\
\hline & Keputusan dasar & 45 & 67 \\
\hline & Inferensi & 30 & 83 \\
\hline & Penjelasan Lanjut & 35 & 80 \\
\hline & Menalar & 30 & 65 \\
\hline & Rata-rata & $\begin{array}{c}38 \\
\text { (Sedang) }\end{array}$ & $\begin{array}{c}75 \\
\text { (Tinggi) }\end{array}$ \\
\hline
\end{tabular}

Tabel di atas menunjukkan bahwa rata-rata kemampuan berpikir kritis mahasiswa mengalami peningkatan. Saat pretest, rata-rata kemampuan berpikir kritis tergolong dalam kategori sedang, sedangkan saat proses pembelajaran tergolong dalam kategori tinggi. Hal ini menunjukkan pembelajaran yang dilakukan dapat meningkatkan kemampuan berpikir kritis pada mahasiswa terutama materi optik. Indikator inferensi mengalami peningkatan tertinggi. Kemampuan inferensi ini berkaitan dengan kemampuan menarik kesimpulan pada makna tersirat berdasarkan beberapa fakta yang dimunculkan. Pada pertemuan pertama, mahasiswa belajar tentang pemantulan cahaya. Beberapa mahasiswa memiliki konsep bahwa pemantulan cahaya berlaku pada bidang datar yang rata. Setelah dilakukan percobaan dengan virtual experiment, mahasiswa menemukan dan berdiskusi dengan kelompoknya terkait pemantulan cahaya. Akhirnya mereka memperbaharui konsepnya tentang hukum pemantulan cahaya serta dosen memberitahu bahwa hukum pemantulan cahaya berlaku pada semua jenis bidang. Pada pertemuan kedua tentang pembiasaan cahaya pada 2 bidang yang memiliki indeks bias berbeda, mahasiswa sering salah dalam menyimpulkan hasil pembiasan cahaya. Setelah melakukan pembelajaran dengan CCM-CCA berbantuan virtual experiment, mahasiswa memahami konsep pembiasan cahaya pada 2 bidang yang berbeda. Selanjutnya di pertemuan terakhir tentang sinar istimewa pada lensa cekung dan cembung. Mahasiswa memahami adanya perbedaan sinar istimewa pada kedua lensa tersebut.

Berdasarkan pembelajaran yang telah dilakukan, mahasiswa mampu merekonstruksi konsepsinya yang salah menjadi konsep ilmiah yang benar karena adanya bukti yang masuk akal melalui media virtual experiment. Perangkat pembelajaran berbasis CCM-CCA juga mampu merubah konseptual mahasiswa saat pembelajaran karena pembelajaran dari awal hingga akhir diarahkan untuk membuat siswa mengalami konflik kognitif dan merubah konseptualnya. Model CCM-CCA ini merupakan alternatif pembelajaran abad 21 karena mampu membuat pembelajaran lebih bermakna melalui proses konflik kognitif dan perubahan konseptual (Makhrus, Wahyudi, Taufik, \& Zuhdi, 2020). Dosen sebagai fasilitator pada pembelajaran berfungsi membantu untuk menyempurnakan konsep mahasiswa di akhir pembelajaran dan di awal pembelajaran berfungsi untuk memberikan konsep-konsep dasar untuk menarik keluar prakonsepsi mahasiswa yang salah. Hal ini dapat terjadi karena pembelajaran dengan CCM-CCA memberikan mahasiswa kesempatan untuk mengkritisi 
konsep yang berbeda dengan konsepsi awalnya sehingga keseimbangan pada kognitifnya terganggu dan mahasiswa akan mencari solusi penyelesaiannya. Virtual experiment menjadi media yang dapat membantu mengkonfrontasi kognitif mahasiswa sekaligus membantu memvisualisasikan konsep sebenarnya sehingga terjadi perubahan konsep pada mahasiswa. Perubahan konseptual akan sangat sulit tercapai tanpa adanya konflik kognitif (Makhrus, Zuhdi, Wahyudi, \& Taufik, 2020). Rangsangan konflik kognitif ini dapat berupa simulasi virtual, demontrasi, ataupun percobaan langsung (Hidayatullah et al., 2020). Selain untuk membantu konfrontasi kognitif mahasiswa, eksperimen virtual ini juga berfungsi sebagai visualisasi atau gambaran tentang konsep-konsep yang abstak dan susah dimengerti mahasiswa. Laboratoium/eksperimen virtual mampu mempermudah dalam memvisualisasikan pembelajaran fisika yang sulit (Aşiksoy \& Islek, 2017). Pembelajaran dengan laboratorium virtual memberi kesempatan peserta didik untuk menghubungkan konsep ilmiah yang sulit dijelaskan secara langsung (Billah \& Widyatmoko, 2018). Di akhir pembelajaran mahasiswa bisa yakin dengan konsep yang baru karena sudah dibuktikan melalui percobaan dengan eksperimen virtual.

\section{KESIMPULAN}

Pembelajaran dengan CCM-CCA berbantuan virtual experiment pada saat proses pembelajaran mampu meningkatkan kemampuan berpikir kritis mahasiswa pada materi optik. Rata-rata kemampuan berpikir kritis mahasiswa pada saat proses pembelajaran berkategori tinggi

\section{SARAN}

Pembelajaran dengan CCM-CCA berbantuan virtual experiment dapat dijadikan alternatif pendekatan pembelajaran yang dapat diterapkan dalam mengajar fisika. Virtual experiment menjadi media yang dapat membantu mengkonfrontasi kognitif mahasiswa sekaligus membantu memvisualisasikan konsep sebenarnya sehingga terjadi perubahan konsep pada mahasiswa.

\section{UCAPAN TERIMA KASIH}

Terima kasih disampaikan kepada Universitas Mataram yang telah mendanai penelitian kami melalui DIPA BLU (PNBP) Universitas Mataram Tahun Anggaran 2020.

\section{DAFTAR PUSTAKA}

Aşiksoy, G., \& Islek, D. (2017). The impact of the virtual laboratory on students' attitudes in a general physics laboratory. International Journal of Online Engineering, 13(4), 2028. https://doi.org/10.3991/ijoe.v13i04.6811

Billah, A., \& Widyatmoko, A. (2018). The Development of Virtual Laboratory Learning Media for The Physical Optics Subject. Jurnal Ilmiah Pendidikan Fisika Al-Biruni, 7(2), 153. https://doi.org/10.24042/jipfalbiruni.v7i2.2803

Dwijananti, P., \& Yulianti, D. (2010). Pengembangan Kemampuan Berpikir Kritis Mahasiswa Melalui Pembelajaran Problem Based Instruction Pada Mata Kuliah Fisika Lingkungan. Jurnal Pendidikan Fisika Indonesia, 6, 108-114.

Firdaus, M., \& Wilujeng, I. (2018). Pengembangan LKPD inkuiri terbimbing untuk meningkatkan keterampilan berpikir kritis dan hasil belajar peserta didik. Jurnal Inovasi Pendidikan IPA, 4(1), 26-40. 
Fiscarelli, S. H., Bizelli, M. H. S. S., \& Fiscarelli, P. E. (2013). International Journal of Learning Interactive Simulations to Physics Teaching: A Case Study in Brazilian. International Journal of Learning and Teaching, 5(1), 18-23.

Fitriani, H., Asy'ari, M., Zubaidah, S., \& Mahanal, S. (2019). Exploring the prospective teachers' critical thinking and critical analysis skills. Jurnal Pendidikan IPA Indonesia, 8(3), 379-390. https://doi.org/10.15294/jpii.v8i3.19434

Hidayatullah, Z., Makhrus, M., \& Gunada, I. W. (2018). Analisis Tingkat Kemampuan Berpikir Kritis Gelombang Mekanik Melalui Pembelajaran Dengan Pendekatan Konflik Kognitif. Jurnal Pendidikan Fisika Dan Teknologi, 4(2), 151-157.

Hidayatullah, Z., Jumadi, Nadhiroh, N., Kartika, E., Nuha, A. A., \& Erlangga, S. Y. (2020). Identifikasi Miskonsepsi Dan Konflik Kognitif Fisika: Kasus Terkait Perubahan Konseptual. EDUSAINS, 12(1), 64-71.

Makhrus, M. (2018). Validitas Model Pembelajaran Conceptual Change Model With Cognitive Conflict Approach. Jurnal Ilmiah Profesi Pendidikan, 3(1), 62-76. https://doi.org/10.29303/jipp.vol3.iss1.55

Makhrus, M., Wahyudi, Taufik, M., \& Zuhdi, M. (2020). Validitas Perangkat Pembelajaran Berbasis CCM-CCA pada Materi Dinamika Partikel. Jurnal Pijar MIPA, 15(1), 5458. https://doi.org/10.29303/jpm.v15i1.1002

Makhrus, M., Widodo, W., \& Agustini, R. (2018). Efektifitas Model Pembelajaran CCMCCA Untuk Memfasilitasi Perubahan Konsep Gaya Pada Mahasiswa. Jurnal Pendidikan Fisika Dan Teknologi, 4(2), 253. https://doi.org/10.29303/jpft.v4i2.810

Makhrus, M., Zuhdi, M., Wahyudi, \& Taufik, M. (2020). Increasing Conceptual Understanding through CCM-CCA Based Learning Device. Jurnal Penelitian Pendidikan IPA, 6(1), 81-84. https://doi.org/10.29303/jppipa.v6i1.347

Pradana, S. D. S., Parno, \& Handayanto, S. K. (2017). Pengembangan Tes Kemampuan Berpikir Kritis Pada Materi Optik Geometri Untuk Mahasiswa Fisika. Jurnal Penelitian Dan Evaluasi Pendidikan, 21(1), 51-64.

Santi, N., Soendjoto, M. A., \& Winarti, A. (2018). Kemampuan Berpikir Kritis Mahasiswa Pendidikan Biologi melalui Penyelesaian Masalah Lingkungan. BIOEDUKASI: Jurnal Pendidikan Biologi, 11(1), 35-39.

Saputra, T. B. R. E., Nur, M., \& Purnomo, T. (2017). Pengembangan Pembelajaran Inkuiri Berbantuan Phet Untuk Melatihkan Keterampilan Proses Sains Siswa. Journal of Science Education And Practice, 1(1), 20-31. 